\title{
NATO Nuclear Deterrence: The Warsaw Summit and Beyond
}

\section{Matthew P. Anderson}

George C. Marshall European Center for Security Studies, http://www.marshallcenter.org

\begin{abstract}
NATO's Deterrence and Defense Posture Review (DDPR, 2012), concluded that "the Alliance's nuclear force posture currently meets the criteria for an effective deterrence and defense posture." In addition to the strategic nuclear forces of France, the United Kingdom, and the United States, NATO's "posture" notably included, then and now, some 200 B-61 "tactical" nuclear bombs stored at sites in five longtime member states. Since release of the DDPR, NATO relations with Russia have deteriorated. It would appear that the American B-61 nukes, soon to be improved through a multibillion-dollar life extension program, are destined to stay in Europe. Beneath the surface, however, linger disquieting questions about the fabled three-C's of NATO's deterrence - its military capability, its credibility and its communication to potential adversaries and partners alike. This paper suggests six nuclear deterrence reforms that NATO should consider following the Warsaw Summit in July 2016 in order to regain the credibility it once had during the Cold War.
\end{abstract}

Keywords: NATO, Nuclear, Warsaw, B-61, Deterrence, Dual Capable Aircraft, Tactical Nuclear Weapons.

\section{Introduction}

NATO, for its part, has consciously and conspicuously de-emphasized nuclear weapons in its defense policy and posture since the end of the Cold War. As a consequence, the Alliance now lacks the policies and capabilities needed to deter, and if necessary to respond to, a limited Russian nuclear strike.

- Dr. Matthew Kroenig, 2015, US Senate testimony ${ }^{1}$

1 Matthew Kroenig, The Renewed Russian Nuclear Threat and NATO Nuclear Deterrence Posture (Washington, DC: Atlantic Council, 2016), accessed February 24, 2016, 
With NATO's Warsaw Summit of July 2016 comes the next opportunity to initiate a much-needed review of the Alliance's nuclear policy. The end of the Cold War saw the Alliance shift its emphasis from collective defense and deterrence to crisis management operations, as witnessed most clearly in the Balkans and Afghanistan. In the process, many argue NATO has neglected traditional nuclear deterrence since the fall of the Berlin Wall over twenty-five years ago. ${ }^{2}$ However, in 2014, everything changed. After Russia's illegal annexation of Crimea, and active support of separatists in Eastern Ukraine, NATO stated, "Russia's aggressive actions against Ukraine have fundamentally challenged our vision of a Europe whole, free, and at peace." ${ }^{3}$ The Syrian Civil War (and associated European refugee crisis), the attacks by the "Islamic State" (IS) in Paris, Istanbul and Brussels and the Turkish downing of a Russian fighter are all events that have forced NATO to address security challenges both to its east and to its south, challenges posed both by state as well as non-state agents. These mean that NATO is spread thin at a time when Russia continues to rattle its nuclear saber with increasing volume. While recent reforms dominate the headlines in the run-up to the Warsaw Summit, the credibility of NATO's nuclear deterrence remains in question in the face of developing threats. This begs the question: what does NATO need to do at the Warsaw Summit to clarify and reinforce its nuclear deterrence posture?

NATO should consider making the following six changes to its nuclear deterrence posture to ensure that it will both offer a credible deterrent to twentyfirst century adversaries and maintain cohesion among its members. These six changes fall under the umbrella of NATO's "three Cs" required for effective deterrence: Capability, Credibility and Communication. ${ }^{4}$ The six recommendations include:

- Adding dual-capable aircraft (DCA) and nuclear strike missions in Poland and Turkey

- Incorporating the Heavy Airlift Wing C-17s into the Prime Nuclear Airlift Force

- Maintaining the status quo in terms of B-61 locations and quantities

- Increasing nuclear readiness (response times) at dual-capable aircraft bases

http://www.atlanticcouncil.org/images/publications/Russian_Nuclear_Threat_0203_ web.pdf.

2 Michael Rühle, The Broader Context of NATO's Nuclear Policy and Posture (Rome: NATO Defense College, 2013).

3 NATO, Wales Summit Declaration, September 5, 2014, accessed January 5, 2016, http://www.nato.int/cps/en/natohq/official_texts_112964.htm.

4 Mr. Heinrich Brauss, NATO Assistant Secretary General for Defence Policy and Planning, reiterated the importance of the " 3 Cs of Deterrence" (Capability, Credibility and Communications) at the NATO Defence Planning Symposium, February 23-25, 2016, NATO School Oberammergau. 
- Creating a "NATO Strategic Deterrence Fund"

- Drafting a NATO nuclear declaratory statement.

\section{Recent NATO Nuclear History}

Unlike the United States and NATO, Russia has placed an increased emphasis on nuclear weapons in its national security planning since the end of the Cold War.

- Matthew Kroenig

In 1954, the Alliance's first nuclear weapons were stationed in Europe, a move that was unanimously welcomed by NATO. ${ }^{5}$ At that time, the initial purpose of these weapons was to counter the overwhelming conventional advantage the Soviet Union had over the Alliance. Since then, the quantities and types of nuclear weapons in Europe have changed dramatically. However, the US B-61 gravity bomb, designed to be dropped by "dual-capable" fighter/bomber aircraft, has remained the only American nuclear weapon in Europe since $1991 .{ }^{6}$

Despite lobbying attempts by certain Allies who wish to withdraw the B-61 from Europe, this controversial "tactical" nuclear weapon has kept its place on the continent thanks to NATO's 2012 Deterrence and Defense Posture Review (DDPR). ${ }^{7}$ Ulrich Kahn explains why the lobbying did not work: "They [the lobbying efforts] have failed, mostly due to the concerns of NATO's easternmost allies who attach a highly symbolic/political value to the only American nuclear weapons currently stationed in Europe. ${ }^{8}$ Moreover, in January 2014, the US Congress offered full funding for a $\$ 10$ billion life extension program (upgrade) for the B-61, with the new version (B-61, mod 12) expected to arrive in $2020 .^{9}$ With an upgraded weapon on the horizon, Turkey, Italy and the Netherlands have committed to replacing their DCA aircraft with the American-made F-35 Stealth Fighter/Bomber. As regards replacing their strike platforms, Belgium and Germany, however, have yet to either make a decision or express firm commitment. ${ }^{10}$

5 George Mindling and Robert Bolton, U.S. Air Force Tactical Missiles 1949-1969: The Pioneers (Morrisville, North Carolina: Lulu.com Publishing, 2011).

6 Hans Kristensen, U.S. Nuclear Weapons in Europe: A Review of Post-Cold War Policy, Force Levels and War Planning (Washington, DC: Natural Resources Defense Council, 2005).

7 "NATO's Nuclear Deterrence Policy and Forces," December 3, 2015, accessed January 5, 2016, http://www.nato.int/cps/en/natohq/topics_50068.htm.

8 Ulrich Kühn, "With or Without You: Germany and NATO," War on the Rocks, November 3, 2015, accessed May 10, 2016, http://warontherocks.com/2015/11/with-orwithout-you-germany-and-nato/.

9 Ibid.

10 Hans Kristensen, "Polish F-16s in NATO Nuclear Exercise in Italy," Federation of American Scientists (FAS), October 27, 2014, accessed March 23, 2016, https://fas.org/blogs/security/2014/10/steadfastnoon/. 


\section{The 3 "Cs" of NATO's Current Deterrence Policy}

The DDPR was based on two principles: Russia is firstly a NATO partner and, secondly, will not direct its sizeable nuclear stockpile in Europe against the Alliance. Neither of these assumptions holds true anymore.

- Karl-Heinz Kamp

\section{A Changed Security Environment}

Today's security environment is completely different from that with which the Alliance was faced in 2012, especially from a nuclear perspective. NATO's publication of the DDPR in 2012 put to rest the public debate over the withdrawal of US nuclear weapons from Europe, initiated in 2009 by Guido Westerwelle, who was Germany's foreign minister at the time. However, according to KarlHeinz Kamp, Academic Director of the German Federal Academy for Security Policy in Berlin, the DDPR "was based on two principles: Russia is firstly a NATO partner and, secondly, will not direct its sizeable nuclear stockpile in Europe against the Alliance. Neither of these assumptions holds true anymore." ${ }^{11}$ Further, Kamp explained in 2015 that "the Russian military is using exercises to simulate the use of nuclear weapons against Poland, is threatening to station ballistic missiles in Kaliningrad and is violating NATO airspace with nuclear-capable aircraft." ${ }^{12}$ This is especially troubling considering Russia's current military policy, which President Vladimir Putin supervised and signed in 2000. "According to this 'escalate to de-escalate,' or 'escalation control' concept, Moscow will use the threat of, or even carry out, limited nuclear strikes in a conventional conflict to force its opponent to capitulate to its terms for peace, ${ }^{13}$ explains Kroenig. This game-changing policy of de-escalation, put into practice in 2014 in Ukraine and Crimea, once again places nuclear deterrence at the top of NATO's agenda.

More specifically, the security environment NATO faces today primarily focuses on threats from two regions: the eastern flank and the southern flank. NATO members in Eastern Europe hope that the Warsaw Summit will focus on implementing and improving the military capabilities agreed upon in Wales in 2014 in order to "improve the deterrence and defence capabilities of NATO visà-vis Russia." ${ }^{14}$ A report by the Rand Corporation dated February 2016 concludes that "A Russian offensive on NATO territory in the Baltics would overwhelm underarmed alliance forces in a matter of hours, leaving NATO with a

11 Karl-Heinz Kamp, "The Agenda of the NATO Summit in Warsaw" (working paper, Federal Academy for Security Policy, Berlin, 2015), accessed May 5, 2016, https://www.baks.bund.de/sites/baks010/files/working_paper_security_policy_9_2 015.pdf. Ibid.

13 Kroenig, The Renewed Russian Nuclear Threat and NATO Nuclear Deterrence Posture.

14 Kamp, "The Agenda of the NATO Summit in Warsaw." 
harsh dilemma: Launch a long, bloody counteroffensive or concede defeat." ${ }^{15}$ While the southern NATO countries acknowledge the concerns held by the eastern members, they do not want the Alliance to lose sight of its focus on what NATO has dubbed "MENA" (Middle East and Northern Africa). ${ }^{16}$ MENA contains threats such as the "Islamic State," failing states, and the unforeseeable fallout of the refugee crisis. These two major issues do not overshadow the future of NATO's nuclear deterrence posture.

\section{The First " $\mathrm{C}$ ": Capability}

The first " $C$ " of traditional deterrence is capability. Specifically, military capability. It is inadvisable to attempt to understand the issue of deterrence in its entirety without first highlighting the conventional (non-nuclear) and nuclear capabilities currently available to the Alliance. Frankly, they leave much to be desired. "As currently postured, NATO cannot successfully defend the territory of its most exposed members," ${ }^{17}$ claims the 2016 RAND study. From NATO's perspective, the line between conventional and nuclear warfare in today's security environment is arguably clearer than it was previously, during the Cold War. This is exemplified by the fact that NATO no longer makes reference to a "continuum" stretching from conventional to nuclear war. ${ }^{18}$ However, Russia's "escalate to deescalate" doctrine has blurred this dividing line. ${ }^{19}$ The situation today is replete with gray areas such as hybrid warfare, cyber warfare, advanced A2AD (anti-access aerial denial) and terrorist attacks ranging from aircraft hijackings to chemical, biological, radiological and nuclear (CBRN) attacks. In theory, in times of war, each of the twenty-eight NATO Allies makes their forces available to the Supreme Allied Commander Europe (SACEUR), a position traditionally held by a US four-star general or admiral. In practice, each nation's political leaders determine when, where, and in what precise capacity they deploy their forces under the NATO flag. We have seen this dynamic in action for over a decade in Afghanistan.

From an overall deterrence perspective, this arrangement proves challenging, as not even the military planners in Brussels know what forces will be available to them at any given time. While admittedly different from an Article $V$ situation in the Baltics, operations in Afghanistan and the Balkans have proven that members are permitted to contribute forces "with caveats," or restrictions. This presents challenges in terms of meeting mission requirements.

15 John Vandiver, "Report: Russia Defeats NATO in Baltic War Game," Stars and Stripes, February 5, 2016, accessed May 6, 2016, http://www.military.com/daily-news/ 2016/02/05/report-russia-defeats-nato-in-baltic-war-game.html?ESRC=airforce_160 209.nl.

16 Kamp, "The Agenda of the NATO Summit in Warsaw."

17 Vandiver, "Russia Defeats NATO in Baltic War Game."

18 Anthony Stroup (Chief, Nuclear, CBRN Defence and Arms Control Policy Branch, NATO International Military Staff), interviewed by the author, May 6, 2016.

19 Kroenig, The Renewed Russian Nuclear Threat and NATO Nuclear Deterrence Posture. 
Russia's revisionist course of action in the East, however, prompted the Alliance to effect a small number of wholesale changes to make its forces more visible to any potential adversary. Speaking at the Munich Security Conference in February 2016, NATO Secretary General Jens Stoltenberg declared that, in the face of a "more assertive Russia," NATO needed "to send a powerful signal to deter any aggression or intimidation." ${ }^{20}$ Since the last Summit in 2014, NATO has sent most of these signals via conventional means.

\section{Conventional}

From a conventional perspective, NATO's focus since the Wales Summit of 2014 has been on implementing the Readiness Action Plan (RAP). The Allies created the RAP to "assure frontline allies that NATO was willing and able to defend their sovereignty against Russian aggression." ${ }^{21}$ NATO describes the plan as containing two pillars: 1) assurance measures and 2) adaptation measures. Assurance measures comprise actions that increase military presence and activity for the purposes of assurance and deterrence, such as raising the number of air policing fighter jets in the Baltics from four to sixteen. Adaptation measures include changes to the Alliance's long-term military posture and capabilities, such as enhancing the responsiveness and capabilities of the NATO Response Force (NRF). ${ }^{22}$

More recently, in February 2016, NATO decided to enhance this presence via multinational rotational contingents. Rotational, or, in NATO lingo, "persistent" forces, as opposed to "permanently" stationed forces, remain an important distinction in the eyes of the Alliance - as well as in the eyes of Moscow. The 1997 NATO-Russia Founding Act, agreed upon two years before the first Central and Eastern European (CEE) democracies joined NATO, states that NATO could defend its (enlarged) territory without the "additional permanent stationing of substantial combat forces." 23 Therefore, in order to not "violate" the act and by extension, potentially escalate tensions with Russia, NATO intends to keep these forces rotational, avoiding the more controversial, "permanent" label. Stoltenberg underscored the importance of the implementation of the RAP in February 2016 at the Meeting of NATO Ministers of Defense in Brussels, stating:

20 "Speech by NATO Secretary General Jens Stoltenberg at the Munich Security Conference," February 13, 2016, accessed March 9, 2016, http://nato.int/cps/en/natohq/ opinions_128047.htm.

21 Alberto Perez Vadillo, "From Munich to Warsaw: NATO rethinks deterrence," British American Security Information Council, February 22, 2016, accessed March 9, 2016, www.basicint.org/blogs/alberto-perez-vadillo-eu-non-proliferation-consortiumresearcher/02/2016/munich-warsaw-nato.

22 "NATO's Readiness Action Plan. Fact Sheet," December 2014, accessed March 9, 2016, http://www.nato.int/nato_static_fl2014/assets/pdf/pdf_2014_12/20141202_ 141202-facstsheet-rap-en.pdf.

23 Provided Moscow exercised restraint in its conventional deployments - see Vadillo, "From Munich to Warsaw." 
We have increased NATO's presence in the eastern part of the Alliance, with enhanced air policing, maritime patrols and robust exercises. We have agreed assurance measures for Turkey - with Patriot batteries, AWACS surveillance planes, and an enhanced maritime presence in the Eastern Mediterranean and in the Black Sea. We have tripled the size of the NATO Response Force to more than 40,000 troops, with the new Spearhead Force at its core. ${ }^{24}$

The actual execution of the RAP and other conventional commitments will no doubt be topics high on the agenda at the upcoming Warsaw Summit.

From a purely American perspective, President Barack Obama announced the European Reassurance Initiative (ERI) in June 2014. Washington originally intended this to be a one-year, \$1 billion "emergency response to Russian aggression." ${ }^{25}$ However, the president's fiscal year (FY) 2017 budget proposes quadrupling funding for the ERI to $\$ 3.4$ billion, up from $\$ 789$ million in FY 2016 . $^{26}$ This funding represents a step in the right direction. It not only helps deter adversaries, but also reassures allies. While these significant improvements on a conventional level undoubtedly send a message, why is this message not reinforced in a nuclear dimension?

\section{Nuclear}

Despite NATO's claims of self-transformation, it appears to be ignoring one of the main pillars of its collective security. In other words, despite Russia's continued nuclear saber-rattling, NATO has failed to highlight any changes to its nuclear deterrence posture or policies - the Allies have remained silent. Nevertheless, this may be intentional, signaling that NATO need not cross the nuclear threshold to fulfill its obligations to its allies in scenarios less than all-out war. ${ }^{27}$ However, further analysis of NATO's nuclear posture underscores the need for reform in the nuclear arena.

NATO's nuclear posture has remained unchanged for years. Technically, it comprises the independent strategic forces of the three nuclear powers of the Alliance: the United States, United Kingdom and France - about 7,800 nuclear weapons in total. ${ }^{28}$ These "strategic" forces include the traditional nuclear triad of bombers, Inter-Continental Ballistic Missiles (ICBMs), and submarines. At any

24 "NATO boosts its defence and deterrence posture," February 10, 2016, accessed March 9, 2016, http://www.nato.int/cps/en/natohq/news_127834.htm.

25 Mark F. Cancian and Lisa Sawyer Samp, "The European Reassurance Initiative," Center for Strategic and International Studies, February 9, 2016, accessed March 30, 2016, https://csis.org/publication/european-reassurance-initiative.

26 Ibid.

27 Schuyler Foerster (Brent Scowcroft Professor of National Security Studies, Eisenhower Center for Space and Defense Studies), interviewed by the author, May 2, 2016.

28 "Nuclear Force Reductions and Modernizations Continue; Peace Operations Increase," Stockholm International Peace Research Institute, June 15, 2015, accessed April 19, 2016, http://www.sipri.org/media/pressreleases/2015/yb-june-2015. 
given time, these three countries could employ their strategic nuclear forces autonomously, or make them available to the Alliance in a NATO capacity. However, NATO doctrine concedes that the "supreme guarantee of the security of the Allies is provided by the strategic nuclear forces of the Alliance, particularly those of the United States." ${ }^{29}$

According to the Stockholm International Peace Research Institute's (SIPRI) Yearbook Summary of June 2015, nine countries currently possess nuclear weapons. ${ }^{30}$ At first glance, the overall balance between NATO countries and Russia appears relatively even. However, the Allies do not generally consider the strategic forces of the US, UK and France to be "NATO" nuclear weapons. This is firstly significant because France refuses to participate in any nuclear planning within NATO and secondly because a Cold War-style strategic nuclear exchange is not the threat NATO worries about. Most experts label these "NATO" weapons, the aforementioned B-61 gravity bombs, "tactical" or nonstrategic nuclear weapons (NSW). The imbalance in terms of "tactical" weapons greatly favors Russia, with an alarming ratio of about $6: 1 .^{31}$ This sizeable disparity in capability can be easily rectified with a few changes to readiness and posture by the Alliance - recommendations which will be addressed later in this paper.

While the three NATO nuclear powers, and their political leaders, always retain possession of and authority over their own national weapons, the Alliance also maintains a unique capability described as "nuclear sharing." In general, "The idea is that one solution to the 'free-rider' problem in NATO's defense is to insist that NATO allies bear some of the financial and political burden of keeping NATO a 'nuclear alliance' by housing forward-deployed U.S. nuclear weapons," explains Jeffrey Lewis. ${ }^{32}$ Under this arrangement, which was "grandfathered in" before the Non-Proliferation Treaty of 1970, the US stores approximately 180 B-61 nuclear gravity (tactical) bombs on five NATO members' soil. ${ }^{33}$

${ }^{29}$ Katarzyna Kubiak and Oliver Meier, “Updating NATO's nuclear posture: Necessary? Feasible? Desirable?" European Leadership Network, November 12, 2015, accessed April 19, 2016, http://www.europeanleadershipnetwork.org/updating-natos-nuclearposture-necessary-feasible-desirable_3312.html.

30 "World nuclear forces," in SIPRI Yearbook 2015, chapter 11, Stockholm International Peace Research Institute, accessed April 19, 2016, https://www.sipri.org/yearbook/ 2015/11.

31 Robert S. Norris and Hans M. Kristensen, "US tactical nuclear weapons in Europe, 2011," Bulletin of the Atomic Scientists 67, no. 1 (2011): 64-73, accessed January 5, 2016, http://bos.sagepub.com/content/67/1/64.full.

32 Jeffrey Lewis, "A Steal at \$10 Billion," Foreign Policy, September 5, 2012, accessed March 30, 2016, http://foreignpolicy.com/2012/09/05/a-steal-at-10-billion/.

33 George Perkovich, Malcolm Chalmers, Steven Pifer, Paul Schulte, and Jaclyn Tandler, Looking Beyond The Chicago Summit: Nuclear Weapons in Europe and the Future of NATO (Washington DC: Carnegie Endowment for International Peace, 2012). 
These "tactical" nuclear bombs, first built in the 1960s, are considered to be the oldest nuclear weapons in the US inventory, and are fully funded by the US taxpayer. ${ }^{34}$ The US plans to modernize the B-61 via a "Life Extension Program" (LEP) costing $\$ 10$ billion - consolidating four versions of the bomb into one single modification, the controversial B-61 Mod $12 .{ }^{35}$ The "controversy" is twofold. In the US, the controversy is rooted in the fact that the estimated cost of the program has ballooned from an initial $\$ 4$ billion to a now-realistic $\$ 10$ billion. Internationally, critics argue that the B-61 LEP, with its increased accuracy and lower yield, makes the weapon appear more usable to military planners. ${ }^{36}$ This, in turn, adds a destabilizing element to the weapon.

Under the nuclear sharing arrangement, in times of war, the US transfers custody of the B-61 to the NATO host nation, which then employs its DCA to drop the weapon on enemy territory. Unfortunately, the DCA "are rapidly reaching the end of their normal service lives, however, and are the only means by which NATO shares the threat of nuclear attack on potential opponents in times of crisis among several Allied nations." ${ }^{37}$ Belgium and the Netherlands currently use the F-16 and Germany and Italy use the Tornado.

The logic behind this arrangement is simple. The Allies share the political and tactical "burden" of actually using nuclear weapons against an adversary. Even allies not directly involved in DCA strike missions regularly contribute via nuclear consultation in the Nuclear Planning Group (NPG). In times of war, these allies cast their vote in favor of, or against, the use of a nuclear strike. Other members, such as Poland with its F-16s, contribute to the nuclear mission in what NATO terms a "SNOWCAT" role. These allies provide non-nuclear capabilities such as the suppression of enemy air defense (SEAD). ${ }^{38}$ SNOWCAT can be anything from the command and control of nuclear forces to the security of weapons on the ground. Put simply, German, Dutch, Belgian or Italian fighter pilots would load American nuclear bombs (stored on European soil) and drop them on the adversary, if called upon. While this concept sounds simple in theory, it has not been devoid of controversy over the past decade.

\footnotetext{
34 "B61 Bombs in Europe and the US Life Extension Program," British American Security Information Council, March 2016, accessed March 30, 2016, www.basicint.org/sites/ default/files/BASIC_B61_briefing_Mar2016.pdf.

35 Lewis, "A Steal at \$10 Billion."

36 "B61 Bombs in Europe and the US Life Extension Program."

37 Edmond E. Seay, Countdown to Chaos? Timelines and Implications of Procurement Decisions for NATO's Dual-Capable Aircraft (Hamburg: British American Security Information Council (BASIC), 2013), accessed January 19, 2016, www.basicint.org/ sites/default/files/nuclear_policy_paper_no_14_final.pdf.

38 Kristensen, "Polish F-16s in NATO Nuclear Exercise in Italy."
} 


\section{The 2nd " $\mathrm{C}$ ": Credibility}

\section{Recent Nuclear Debates}

Credibility is the second " $\mathrm{C}$ " of deterrence, often termed a measure of the political will to use the military capability available. In order to understand where NATO currently stands in terms of its nuclear credibility, it is important to expand on where it has stood in the recent past. NATO is no stranger to debates on nuclear issues. There is an obvious benefit to frank, internal discussions on issues of debate within the Alliance. Public debates, however, within NATO, can have a negative effect on the Alliance's credibility. This holds especially true if these debates plant seeds of doubt in the adversary's mind. While the newer members of NATO generally value the nuclear status quo, many Western European nations have preferred, in the recent past, to reduce the role of nuclear weapons significantly. ${ }^{39}$ In 2014, Dr. Robert Czulda explained the background behind the thinking of one proponent of this mindset, Germany:

The biggest political advocate of a complete withdrawal is Germany, which would be the first casualty of tactical nuclear weapons during the Cold War, just like Poland. According to the analysis of NATO in the 1950s (Carte Blanche 1955 and Lion Noire 1957 exercises), in the case of aggression by the Warsaw Pact on Western Europe, even a limited use of nuclear weapons would render German territory uninhabitable due to both the explosion and radiation. This fear and the pacifist movement that has been growing since the 1970s have made the Germans the biggest opponents of nuclear weapons in Europe. ${ }^{40}$

This "pacifist" movement surfaced again in 2009 when Germany led the call to withdraw US nuclear weapons from Europe. Referencing Obama's Prague speech of 2009, Germany's Foreign Minister, Guido Westerwelle, called for Germany to be "free of nuclear weapons" and added,

We will take President Obama at his word and enter talks with our allies so that the last of the nuclear weapons still stationed in Germany, relics of the Cold War, can finally be removed. ${ }^{41}$

To be fair, this view was only held by one junior faction within the German government, not the country as a whole. While the German public is predominantly anti-nuclear, its government generally recognizes the importance of nuclear sharing within the Alliance. ${ }^{42}$ Nonetheless, Belgium, Norway, Luxembourg

39 Robert Czulda, "NATO Tactical Nuclear Weapons in Europe - towards Modernisation or Withdrawal?" Baltic Security and Defence Review 17, no. 2 (2014): 80-111.

40 Ibid.

41 Sonia Phalnikar, "New German government to seek removal of US nuclear weapons," Deutsche Welle, October 25, 2009, accessed January 19, 2016, http://www.dw.com/ en/new-german-government-to-seek-removal-of-us-nuclear-weapons/a-4824174.

42 Dr. Jeffrey Larsen (Director, Research Division, NATO Defense College, Rome, Italy), email message to author, February 24, 2016. 
and the Netherlands supported Berlin's bold initiative heading into NATO's 2010 Lisbon Summit. However, the US secretary of state at the time, Hillary Clinton, announced a key policy principle at a meeting of NATO foreign ministers in April 2010 (prior to the Lisbon Summit) in Tallinn, Estonia - namely, that US tactical nuclear weapons would remain in Europe, avoiding "consternation" throughout the Alliance. ${ }^{43}$ Later in 2010, NATO released its "Strategic Concept," which specifies that NATO's deterrence will be based on an appropriate combination of nuclear and conventional capabilities. ${ }^{44}$

The Alliance followed this up with the release of the DDPR in 2012. The DDPR, announced at the Chicago Summit, does not recommend any changes to NATO's nuclear posture. Instead, it simply glosses over the "conflicting nuclear interests within NATO" ${ }^{45}$ by stating that "nuclear weapons are a core component of NATO's overall capabilities for deterrence and defence" and that "the Alliance's nuclear posture currently meets the criteria for an effective deterrence and defence posture." ${ }^{46}$ Aside from these public documents, however, NATO members have often avoided public discussions on nuclear weapons as domestic disputes continue to heat up. ${ }^{47}$ This proves worrying in light of Moscow's recent rattling of its nuclear saber.

\section{NATO's Current Nuclear Policy}

Nuclear policy, set by heads of state, plays a major role in determining NATO's credibility and political will. In fact, Michael Rühle, current Head of the Energy Security Section of NATO's international staff, argues, "Nuclear policy always trumps posture. It demonstrates solidarity amongst all twenty-eight members from the Head of State level. Nothing is more powerful in the eyes of an adversary." ${ }^{48}$ Historically, since the formation of the Alliance in 1949, NATO summits have served as the primary opportunity for the NATO heads of state to evaluate and provide strategic direction for Alliance activities. These are not regular meetings, but simply an important part of the Alliance's decision-making process. For example, NATO uses summits to introduce new policy, invite new

43 Damon V. Coletta, "Deterrence Logic and NATO's Nuclear Posture," Strategic Studies Quarterly 7 (Spring 2013): 69-92.

44 NATO, “Active Engagement, Modern Defence," November 19, 2010, accessed May 12, 2016, http://www.nato.int/cps/en/natolive/official_texts_68580.htm.

45 Kamp, "NATO Summit in Warsaw."

46 NATO, "Deterrence and Defence Posture Review," May 20, 2012, accessed May 12, 2016, http://www.nato.int/cps/en/SID-4E5D5633-EACD44C0/natolive/official_texts_ 87597.htm.

47 Rachel Staley Grant, "Rethinking nuclear deterrence and burden-sharing," British American Security Information Council (BASIC), July 22, 2013, accessed January 19, 2016, http://www.basicint.org/news/2013/rethinking-nuclear-deterrence-and-burdensharing.

48 Michael Rühle, "The Broader Context of NATO's Nuclear Policy and Posture," Working Paper No. 89 (Rome: NATO Defense College, January 2013). 
members, or even show a coordinated response to a specific opponent's actions. Since NATO's inception, there have only been 26 NATO summits. ${ }^{49}$ Traditionally, the declaration made at the conclusion of each summit announces significant changes or anticipated statements. Naturally, any changes to the Alliance's nuclear posture would be included in these declarations. For example, in 2010 the Lisbon Summit saw the publication of a new Strategic Concept (typically used as a 10-year road map) and called for the creation of a DDPR. These two documents serve as the basis for NATO's nuclear policy. Key statements include:

- "The fundamental purpose of NATO's nuclear forces is deterrence."

- "Deterrence, based on an appropriate mix of nuclear and conventional capabilities, remains a core element of NATO's overall strategy."

- "Nuclear weapons are a core component of the Alliance's overall capabilities for deterrence and defense alongside conventional and missiledefense forces."

- "NATO is committed to arms control, disarmament and non-proliferation, but as long as nuclear weapons exist, it will remain a nuclear alliance."

- "The Nuclear Planning Group provides the forum for consultation on NATO's nuclear deterrence." 50

On May 22, 2015 Stoltenberg announced that the next summit would take place on July 8, 2016 in Warsaw. To this end, he stated, "We are already implementing the biggest reinforcement of our collective defence since the end of the Cold War. In Warsaw, we will chart the course for the Alliance's adaptation to the new security environment, so that NATO remains ready to defend all Allies against any threat from any direction." ${ }^{51}$ While much of the focus in the run-up to Warsaw has been on the recent RAP and Exercise Trident Juncture, both conventional improvements to the Alliance, public discussions from NATO on its nuclear initiatives remain muted.

The concept that the Alliance has no enemies is one current policy that weakens the credibility of NATO's deterrence posture. This defies the traditional logic of deterrence logic. In order to deter an adversary, one must first identify its adversary. The politically convenient stance of "NATO has no enemies" deters nobody. NATO must define what and whom, exactly, it believes constitute the greatest threats to the Alliance. Is there a need to deter not only

49 NATO, "Summit Meetings," November 6, 2015, accessed January 5, 2016, http://www.nato.int/cps/en/natolive/topics_50115.htm.

50 NATO, "NATO's Nuclear Deterrence Policy and Forces," December 3, 2015, accessed January 5, 2016, http://www.nato.int/cps/en/natohq/topics_50068.htm.

51 NATO, "NATO Secretary General announces dates for 2016 Warsaw Summit," May 22, 2015, http://www.nato.int/cps/en/natohq/news_120085.htm. 
state actors such as Russia, North Korea, Pakistan and China, but also non-state actors such as IS as well? By doing so, NATO can then identify the corresponding requirements in terms of force, policies and budget to overcome these adversary-specific threats. Warsaw, and its unique geographical location, provides the ideal opportunity to make the necessary reforms to add credibility to NATO's nuclear deterrence.

\section{The 3rd "C": Communication}

\section{Bridging the Strategic Communication Gap}

The final " $C$ " is communication. For NATO to deter an adversary successfully it must communicate its capabilities and credibility in a manner the adversary understands. Without this, the first two "Cs" are arguably worthless. For example Russia, and especially Putin, have consistently demonstrated that strength is what is understood and respected. While diplomacy should be the first port of call, NATO must always enter diplomatic negotiations from a position of strength. Stoltenberg underlined this in January 2016 saying, "There is no contradiction between increasing the strength of NATO and engaging with Russia. Indeed, it is only by being strong that we can develop a cooperative and constructive relationship." 52

In order to do this, NATO must improve its strategic communication. Specifically, it must change its nuclear mindset and "must not consider discussion of nuclear developments as off limits because of its controversial nature." 53 This is not a new idea. In fact, prior to the 2012 summit in Chicago, members of the Carnegie Endowment wrote, "To avoid such a cascading loss of confidence, NATO leaders must prepare the Alliance to reach some fundamental decisions on its deterrence and defense posture after the Chicago Summit." 54 If this is not accomplished, however, as George Perkovich explains, "it will begin to lose its ability to take collective decisions on NATO's nuclear capabilities and policies." 55 Only then will the Alliance avoid the inevitable "disarmament by default" of not addressing the need for modernization in the nuclear arena. ${ }^{56}$ One example of this "disarmament by default" is Germany's reluctance to replace Tornado aircraft for the nuclear strike mission. While it has agreed to extend the life of the Tornado, Germany risks losing the ability to perform nuclear strike mission completely if it does not decide on a Tornado replacement soon.

52 The Secretary General's Annual Report 2015 (Brussels: NATO Public Diplomacy Division, 2016), accessed May 12, 2016, http://www.nato.int/nato_static_fl2014/ assets/pdf/pdf_2016_01/20160128_SG_AnnualReport_2015_en.pdf\#page=27.

53 Rühle, "The Broader Context of NATO's Nuclear Policy and Posture."

54 Perkovich et al., Looking Beyond The Chicago Summit.

55 Ibid.

56 Steven Pifer, "NATO, Nuclear Weapons and Arms Control," Arms Control Series, Report 7 (Brookings, July 2011), accessed January 20, 2016, https://www.brookings.edu/wp-content/uploads/2016/06/0719_arms_control_ pifer.pdf. 
This, however, would require public discussion on the funding of a nuclear-capable aircraft - a topic that political leaders want to avoid. Germany identified the DCA capability gap well over a decade ago, yet is still dragging its feet with regard to identifying a replacement. This, in and of itself, is communicating intentions to adversaries that erode the overall effect of deterrence.

NATO's continued silence on the nuclear front may also prove troubling to those Allies and partner nations looking for reassurance in the face of Russia's recent posturing. Denis Healey, the British defense minister in the late 1960s, once said, "It takes only five percent credibility of American retaliation to deter the Russians, but ninety-five percent credibility to reassure the Europeans." ${ }^{57}$ Healey's "deterrence theory" still rings true nearly fifty years later as NATO continues to struggle to achieve a balance between deterrence and reassurance. For example, the Alliance's 1997 NATO-Russia Founding Act states the "three nos," claiming it had "'no intention, no plan, and no reason' to deploy nuclear weapons on the territory of new member states." ${ }^{58}$ This statement was intended to reassure Moscow that the expansion from sixteen to twenty-eight members was non-threatening. However, Matthew Karnitschnig, in his 2014 article, claims "NATO's Baltic members and Poland argue that Russia is in clear violation of the act and that the Alliance is no longer obliged to adhere to it." 59 Furthermore, John Kornblum, a former US assistant secretary of state for European affairs who helped draft and negotiate the act, explained a rarely discussed nuance to the agreement: "It says if conditions change, all bets are off. There are all kinds of escape clauses if the other side isn't sticking to its commitment. Clearly, the Russians have broken virtually all of theirs. There's no way you can say the conditions are as harmonious as when it was signed." ${ }^{60}$ Expanding the nuclear strike mission to include a Central or Eastern European country, for example, could help reassure the Allies to the east, yet not violate the Founding Act.

Newer NATO members, especially many of the CEE countries, view the presence of American B-61s in Europe as their symbolic link to the US. This link, without question, enticed these recent members to join the Alliance in the first place. Publically accessible sources claim that there are approximately 150-200 American B-61 gravity bombs located in Germany, Belgium, the Netherlands, Italy and Turkey. ${ }^{61}$ For the CEE countries, the weapons serve as a daily reminder that this transatlantic partnership is still alive and well. This partnership

57 Denis Healey, The Time of My Life (London: Michael Joseph, 1989), 243.

58 Luis Simón, "NATO," in Tactical Nuclear Weapons and Euro-Atlantic Security: The Future of NATO, ed. Paolo Foradori (New York: Routledge, 2013), 107-124.

59 Matthew Karnitschnig, "Pact With Russia Keeps NATO Bases at a Distance, But Should It?" Wall Street Journal, September 3, 2014, accessed February 29, 2016, http://blogs.wsj.com/brussels/2014/09/03/qa-1997s-nato-russia-founding-act/tab/

60 print/.

Ibid.

61 Norris and Kristensen, "US tactical nuclear weapons in Europe, 2011." 
is critical to the credibility of the "an attack on one, is an attack on all" policy, or Article V of the North Atlantic treaty. From the perspective of CEE, this political reassurance cannot be understated at a time when the Obama administration continues to pursue its explicit efforts to "pivot" to the Pacific. In addition, the CEE countries fear that Russia's invasion of Ukraine, and of Georgia in 2008, "may not be isolated incidents, but rather symptomatic of a grander ambition in Moscow to restore a Russian sphere of influence in the area of the former Soviet Union, and that these plans could come to threaten regional stability and NATO members directly." ${ }^{12}$ Improved nuclear strategic communication improves the perception of political will, and therefore improves deterrence.

\section{Money Talks}

Spending money wisely on defense is yet another means by which the third " $\mathrm{C}$ " can be effectively used to communicate intentions, and thereby deter adversaries. It demonstrates political will as well as effectively communicates resolve and priorities. Stoltenberg highlights this in the Secretary General's Annual Report for 2016: "While there are many ways in which Allies demonstrate solidarity, one is through investing in defence." ${ }^{\prime 3}$ Unfortunately, the lack of spending on defense also sends a message to adversaries. Former US Secretary of Defense Robert Gates put Europe on alert in 2011, saying "The blunt reality is that there will be dwindling appetite and patience in the US Congress-and in the American body politic writ large-to expend increasingly precious funds on behalf of nations that are apparently unwilling to devote the necessary resources or make the necessary changes to be serious and capable partners in their own defense." ${ }^{64}$ This statement, combined with initiatives such as the German-led proposal to remove American B-61s from Europe, continues to chip away at confidence in the true cohesion of the Alliance. Even the front-runner for the Republican presidential nomination, Donald Trump, fired a warning shot across NATO's bow at a rally in Wisconsin in May 2016, saying that Allies "are not paying their fair share" and that "either they pay up, including past deficiencies, or they have to get out. And if it breaks up NATO, it breaks up NATO." 65 Comments like this from Trump, despite their context, only add fuel to the fire of Russian attempts to capitalize on ways to divide the Alliance.

NATO sets a target for members to spend at least $2 \%$ of their gross domestic product (GDP) on defense, and for at least $20 \%$ of that defense spending to

62 Matthew Kroenig, "Facing Reality: Getting NATO Ready for a New Cold War," Survival: Global Politics and Strategy 57, no. 1 (February-March 2015): 49-70.

63 The Secretary General's Annual Report 2015.

64 Robert Burns, "Gates blasts NATO, questions future of alliance," Associated Press, June 10, 2011, http://www.salon.com/2011/06/10/eu_gates_nato_doomed/.

65 “Trump Fine With 'Breakup' of NATO," Newsmax, May 2, 2016, accessed May 2, 2016, www.newsmax.com/Headline/trump-nato-break-up/2016/04/02/id/722004/. 
be on major equipment, including research and development. ${ }^{66}$ Since very few members meet this target, the declaration following the 2014 Wales Summit watered down the commitment by agreeing that those not meeting the $2 \%$ pledge must at least:

- Halt any decline in defense expenditure

- $\quad$ Aim to increase defense expenditure in real terms as GDP grows

- Aim to move towards the $2 \%$ guideline within a decade. ${ }^{67}$

In the 2016 report, Stoltenberg further released information to show how each country within NATO was progressing towards this goal, nearly eighteen months after the pledge. In the report, he says:

Against the $2 \%$ and $20 \%$ goals combined, only three [out of 28] NATO countries met the guideline to which all NATO members have agreed. Despite the fact that many NATO countries increased their defence spending in 2015, cuts by some with larger economies meant that overall NATO defence spending is estimated to have decreased in $2015 .^{68}$

Herein lies the problem. Why are so many American leaders unhappy with the financial imbalance across the Alliance? Again, Stoltenberg explains, "In 2015, the US accounted for $50 \%$ of Alliance Gross Domestic Product (GDP) and $72 \%$ for the total NATO defense expenditures." ${ }^{69}$ As US Vice President Joe Biden has said many times throughout his political career, "Don't tell me what you value. Show me your budget, and I'll tell you what you value." 70 Frankly, the US has always borne a disproportionate amount of NATO's defense investment. However, since the end of the Cold War, this imbalance has grown markedly. $^{71}$

While many NATO countries argue that the "output" of a country is more important than an objective metric like percentage of GDP, GDP is the yardstick NATO has chosen. Perhaps more telling from an adversary's perspective are trends in defense spending within specific countries, especially those within NATO that are supposed to be "united" and recommitted the $2 \%$ metric in the wake of the 2014 Wales Summit. In a piece published in Defense One in 2015, Kedar Pavgi shows the percentage change in defense spending since the 2014 Ukraine crisis and Wales $2 \%$ pledge. Namely, Pavgi highlights that the easternmost countries in NATO have shown the biggest increases in defense spending

66 NATO, Wales Summit Declaration.

67 Ibid.

68 The Secretary General's Annual Report 2015.

69 Ibid.

70 “Biden's Remarks on McCain's Policies," New York Times, September 15, 2008, accessed May 2, 2016, www.nytimes.com/2008/09/15/us/politics/15text-biden.html.

71 The Secretary General's Annual Report 2015. 
since Russia's illegal annexation of Crimea and occupation of eastern Ukraine. ${ }^{72}$ This is an encouraging sign that countries are taking the threat seriously and are trying to adjust their defense spending accordingly. Unfortunately, countries such as Ukraine and Georgia recently learned that it is impossible to create professional militaries overnight. More recent reports suggest that trends might be changing for the better. According to Marc Champion, "NATO members have, finally, begun to reverse declines in defense spending. The US pays 22 percent of NATO's roughly $\$ 2.3$ billion common budget (a reasonable share given that the US accounts for 50 percent of total alliance GDP). It continues to shoulder far too much of actual spending, but dissolving the alliance makes sense only if the US can afford to walk away from European commitments. It can't." ${ }^{73}$ Continued emphasis on appropriate levels of defense spending speaks volumes to adversaries as they see improved capabilities that demonstrate political will. Poland, as an ally that has "put its money where its mouth is," provides the perfect venue not only to continue with current reforms, but also to expand these reforms to the nuclear arena.

\section{Recommendations}

Work by traditional nuclear deterrence theorists like Brodie, ${ }^{74}$ Snyder $^{75}$ and Schelling ${ }^{76}$ remains relevant to NATO in the twenty-first century, though these theorists all hold slightly different viewpoints. NATO combines and simplifies these deterrence theorists' varying approaches by continuing in its use of the "Three Cs" as a means to gauge deterrence. Proving a negative, such as why deterrence actually works, remains nearly impossible. However, considering the aforementioned deficiencies in these three pillars, below are six changes that NATO should consider making to its posture of nuclear deterrence in Warsaw.

72 Kedar Pavgi, "NATO Member's Defense Spending, in Two Charts," Defense One, June 22, 2015, accessed April 29, 2016, http://www.defenseone.com/politics/2015/06/ nato-members-defense-spending-two-charts/116008/.

73 Marc Champion, "Trump Asks a Good Question About NATO (and Botches It)," Bloomberg View, April 5, 2016, accessed April 29, 2016, www.bloombergview.com/ articles/2016-04-05/trump-asks-right-question-botches-answer-on-nato.

74 Bernard Brodie, ed., The Absolute Weapon: Atomic Power and World Order (New York: Harcourt, Brace and Company, 1946); Bernard Brodie, Strategy in the Missile Age (Princeton, NJ: Princeton University Press, 1959).

75 Glenn Snyder, Deterrence and Defense: Toward a Theory of National Security (Princeton: Princeton University Press, 1961).

76 Thomas Schelling, The Strategy of Conflict (Cambridge: Harvard University Press, 1960); Thomas Schelling, Arms and Influence (New Haven, CT: Yale University Press, 1966). 


\section{\# 1: Adding DCA and strike missions in Poland and Turkey}

The 2016 RAND study publicly identifies a glaring weakness in NATO's capabilities in the Baltic region: "As presently postured, NATO cannot successfully defend the territory of its most exposed members." "77 "The outcome was, bluntly, a disaster for NATO," the report said. "Across multiple plays of the game, Russian forces eliminated or bypassed all resistance and were at the gates of or actually entering Riga, Tallinn, or both, between 36 and 60 hours after the start of hostilities." ${ }^{78}$ Tweaking the region's nuclear posture would quickly shrink this gap. Such a move is not unprecedented in NATO's history. In fact, conventional military disadvantage, by comparison to the USSR, is the reason why the US placed nuclear weapons in Europe in the first place.

Adding a NATO nuclear strike mission to Polish F-16s would both reassure the Allies on the eastern flank and deter Russia by showing strength and solidarity within the Alliance. Since NATO would not be moving any weapons or creating nuclear storage facilities in Poland, it would not be in violation of the NATO-Russia Founding Act of 1997. Under a bilateral US-Polish treaty, the Alliance already uses the Lask Air Base as the primary base for NATO aircraft deploying to Poland on a temporary rotational basis. In addition, Polish F-16s already participate in the annual NATO Steadfast Noon-STRIKEVAL exercises in a non-nuclear role. ${ }^{79}$ Polish aircraft would simply need to be made nuclear capable and, with minimal training, they would be operational.

Critics of NATO tactical nuclear weapons often point to the unrealistic ability of DCA aircraft to cover the distance required in an actual strike scenario. Primarily, crossing long distances from Western European bases to combative environments containing modern Anti-Access/Aerial Denial (A2AD) systems seems not merely unrealistic, but also suicidal. However, Lask Air Base in Poland solves this geometry problem. It is located just 178 miles from the Belarusian border and 201 miles from the Russian border at Kaliningrad Oblast. As Hans Kristensen describes, "At a speed of 1,800 kilometers per hour (1,110 mile/hour, or Mach 1.47), an F-16 launched from Lask AB would be able to reach Kaliningrad in 12 minutes and Moscow in less than an hour." ${ }^{80}$

How realistic this recommendation politically may be is debatable. In December 2015, the new Polish government raised eyebrows when the undersecretary of state, Tomasz Szatkowski, told Polsat News 2 that Poland was taking "concrete steps" towards joining NATO's nuclear sharing arrangement. ${ }^{81}$ On the other hand, the Polish ministry of defense promptly denied this, saying that

\footnotetext{
77 Vandiver, "Russia Defeats NATO in Baltic War Game."

78 Ibid.

79 Kristensen, "Polish F-16s in NATO Nuclear Exercise in Italy."

80 Vandiver, "Russia Defeats NATO in Baltic War Game."

81 Hans M. Kristensen, "Adjusting NATO's Nuclear Posture," Federation of American Scientists, December 7, 2015, accessed March 23, 2016, http://fas.org/blogs/ security/2015/12/poland/.
} 
"Poland is not engaged in any work aimed at joining NATO's nuclear sharing program." 82 One might logically conclude that Szatkowski's statement demonstrates the deepening of discussions within the Alliance. On the other hand, it may simply represent a statement of political interest by an official of a new government. Either way, the subsequent Polish denial speaks volumes in terms of the continued secrecy of all things nuclear within NATO. As one NATO official said to The Guardian in 2015, "We cannot go into detail on our nuclear discussions. These are internal, sensitive and classified matters. What I can say is that NATO continuously assess all aspects of Russia's military activities, including Russia's nuclear rhetoric." $^{83}$

Turkey's return to the nuclear strike mission the Turkish Air Force previously maintained for would prove much simpler, and would only require approximately one year to become operational again. ${ }^{84}$ Given Russia's recent actions in Syria, it makes sense to maintain a nuclear capability in the southeast portion of the Alliance. Most experts agree that full-scale nuclear war is not what keeps them up at night. Rather, is regional conflicts escalating between nuclear powers by means of an accident or mistake. Turkey's shooting down of a Russian fighter aircraft in November 2015 following a violation of airspace lasting seventeen seconds, captured on video, perfectly illustrates how such a scenario could unfold. Given Russia's expression of willingness to use nuclear weapons as a "de-escalation" technique, maintaining a strike role in this region would be prudent. If Russia knew that a NATO nuclear option was present in the area, it may deter such "de-escalating" nuclear options. Locating nuclear capability in Turkey would also provide NATO with options to counter unpredictable actions by Iran, Pakistan and India, if necessary in the future.

\section{\# 2: Incorporating the Heavy Airlift Wing C-17s into the Prime Nuclear Airlift Force}

Finding creative ways for newer members to contribute to the nuclear mission remains difficult. Russia interprets most moves in this direction as escalatory by nature. Adding the twelve-nation Strategic Airlift Capability (SAC), operated by the multinational Heavy Airlift Wing (HAW), to the US's Prime Nuclear Airlift Force (PNAF) provides the Alliance with a means to rapidly airlift Europe-based US tactical nuclear weapons to any airfield in the theater of operations. This recommendation would save money both from a strategic and a tactical perspective, and would not be perceived as escalatory. It would also enable NATO to solve the aforementioned geometry problem by giving the SACEUR the ability to launch nuclear strike missions from any airfield, not just the six bases cur-

82 Ibid.

83 Ewen MacAskill, "NATO to review nuclear weapon policy as attitude to Russia hardens," Guardian, June 24, 2015, accessed March 23, 2016, www.theguardian.com/ world/2015/jun/24/nato-to-review-nuclear-weapon-policy-as-attitude-to-russiahardens.

${ }^{84}$ Hans Kristensen, interviewed by the author, April 1, 2016. 
rently housing the B-61s. NATO could quickly transfer the B-61s to the C-17, and store them there on a short-term basis - essentially serving as a temporary vault. This dispersal concept offers a very visible signal that would also be a means by which to deter Russia and provide escalatory options to the Alliance, without actually generating strike sorties.

By expanding nuclear airlift capabilities to the twelve SAC nations, the Alliance would also create an alternative, non-escalatory form of nuclear sharing. This sharing would simultaneously ensure wider participation in the nuclear mission, reassure those states seen as most vulnerable to external threat and relieve the US of shouldering the entire financial load of nuclear airlifting. These twelve SAC nations include ten NATO members and two NATO Partnership for Peace nations that are generally not involved in NATO's nuclear posture. The NATO participants already include the program's host, Hungary, as well as Bulgaria, Estonia, Lithuania, the Netherlands, Norway, Poland, Romania, Slovenia and the US. Sweden and Finland make up the two Partnership for Peace nations already committed to the SAC. ${ }^{85}$ Many of these nations do not currently participate in NATO's nuclear posture other than by their membership in the Nuclear Planning Group (NPG). This allows them to contribute in a highly concrete manner. As for Sweden and Finland, this is a non-escalatory manner to put "skin in NATO's nuclear game" in a manner never seen before.

This option may indeed be realistic. The HAW achieved Full Operational Capability (FOC) in 2012 and already includes former crew members from the US Air Force's $4^{\text {th }}$ Airlift Squadron, the Department of Defense's (DoD) only nuclear airlift squadron. ${ }^{86}$ The SAC concept represents a groundbreaking initiative in the field of smart defense and the pooling and sharing of defense capabilities. It provides a blueprint for the cost-effective sharing of capability and capacity that NATO could adopt in other areas as well. According to its website,

The Strategic Airlift Capability, established in September 2008, is an independent and multinational program that provides this crucial capability to its 12 partner nations by owning and operating three Boeing C-17 Globemaster III long-range cargo jets. SAC is based at the Hungarian Defence Forces (HDF) Papa Air Base in Papa, Western Hungary.

Essentially, the twelve nations share the available flight hours of the three aircraft that can "be used for missions without the prerequisite to consult with the other participants to serve the needs of their national defense, NATO, EU or UN commitments and humanitarian relief efforts." ${ }^{88}$ In order to make the

85 "The Strategic Airlift Capability (SAC)," SAC website, accessed March 23, 2016, https://www.sacprogram.org/en/Pages/The\%20Strategic\%20Airlift\%20Capability.aspx. The Strategic Airlift Capability is operated by the Heavy Airlift Wing in Hungary with 3 C-17s.

86 Blake Jones, interviewed by the author, March 22, 2016.

87 "The Strategic Airlift Capability (SAC)."

88 Ibid. 
nuclear airlift proposal a reality, however, the US would need to "share" with, and trust, its Allies to an unprecedented extent.

Currently, the US Prime Nuclear Airlift Force (PNAF) crews maintain strict standards of accountability via the Personnel Reliability Program (PRP). PRP is the DoD's mechanism to ensure that all personnel who interact directly with nuclear weapons are of essentially sound body and mind. Obviously, in order to expand the PRP to NATO Allies, administrative changes, involving significant risk analysis, are required. While custody and possession of the weapons would likely remain with an American courier crew member, the remaining crew positions of pilot and loadmaster could be filled by other HAW nations. Ultimately, what better "reassurance" can the United States give to its concerned NATO Allies than allowing them access to and responsibility for transporting its most devastating weapons? A precedent already exists by which the Department of Energy and the DoD each honor the other's version of PRP in order to accomplish their mission.

There could not be a more ideal time to launch the training required to incorporate the HAW C-17 crew members and maintainers into the nuclear airlift business. In 2020, the US will begin to replace its current B-61 nuclear bombs in Europe with a new B-61-12 version. ${ }^{89}$ This massive nuclear airlift of approximately $200 \mathrm{~B}-61 \mathrm{~s}$ to and from Europe from the US will serve as strong deterrence in and of itself. The B-61-12 model, seen as controversial by pacifists due to its new combination of low yield and guided tail kit upgrades, would surely be better received by the European public if the SAC (as opposed to the US) executed the swap-out.

\section{\#3: Maintaining the status quo in terms of B-61 locations and quantities}

While nuclear disarmament talks have subsided as a result of the current security environment, the tide will surely turn once relations with current adversaries shift. Looking back at the "Russia is a strategic partner" era of 2009, the Alliance is wise to have made the collective decision not to disarm. By maintaining the current B-61 tactical nuclear weapon posture in all five of the current host nations, NATO scores easy political and operational points. Firstly, the Alliance maintains the moral high ground (and potential future diplomatic advantage) by honoring the 1997 NATO-Russia Founding Act, as it has not placed nuclear weapons on any "new" member's soil. This may seem trivial, but the minute Russia violated Ukraine's territorial integrity, it also violated the 1994 Budapest Memorandum, which included security assurances for Ukraine. ${ }^{90}$ Avoiding tempting "tit for tat" violations gives the Alliance, and the US, future leverage in arms treaties when dealing with Russia. This could prove fruitful

89 British American Security Information Council, "B61 Bombs in Europe and the US Life Extension Program."

90 Steven Pifer, "Mr. Lavrov, Russia, and the Budapest Memorandum," Brookings, January 28, 2016, accessed April 1, 2016, http://www.brookings.edu/blogs/order-fromchaos/posts/2016/01/28-russia-lavrov-budapest-memorandum-pifer. 
when NATO eventually addresses the massive difference in tactical nuclear weapon stockpiles between the US and Russia. Kristensen and Robert Norris estimate that Russia maintains three-thousand tactical nukes, while the US maintains approximately five-hundred. ${ }^{91}$ Secondly, NATO stands firm with regard to its continued public narrative on the importance of the nuclear dimension of the Alliance. Finally, it keeps Western European skin in the game. At a time when there is obvious disagreement on the value of these weapons in Europe, this cannot be understated. Dr. Jeffrey Larsen's 2006 report for the NATO Public Diplomacy Division describes the unique relationship between the United States and the host nations:

It appears that the United States maintains its nuclear weapons in Europe primarily because it thinks its European allies want it to continue to do so. The European DCA states, on the other hand, remain committed to the nuclear mission largely because they think the United States expects them to do so, remaining reluctant partners in the DCA mission. There is no consensus on the need for nuclear weapons in the Alliance. Both sides are talking past one another - or more accurately, not talking to one another. Nobody wants to rock the boat.

Admittedly, Larsen's quote is somewhat outdated. The security environment has changed drastically over the last decade. However, one thing remains the same: Germany has still not decided on a replacement aircraft for its nuclear-capable Tornado. Instead, it has kicked the can down the road by means of a life-extension program. It is safe to assume, therefore, that while Germany has proven its support for the nuclear mission on a passive level, it has yet to invest the required resources to convince the naysayers that it is serious about its long-term commitment to the nuclear strike mission. If Germany is allowed to "disarm by default," then it may lead the other DCA nations down a similar path.

\section{\#4: Increasing nuclear readiness (decreasing response times) at DCA bases}

According to the 2011 GAO report, "Although NATO has no standing operational plans for the use of nuclear weapons, the United States and certain NATO allies provide forces and are required to maintain the ability to be on alert for nuclear operations within a 30-day, 180-day, or 365-day period." ${ }^{92}$ When asked about these numbers, Kristensen expanded on the GAO report by saying, "They don't explain what that means, but as far as I have been able to gauge, it looks like the United States' DCA in Europe is one month, Turkey is

91 Norris and Kristensen, "US tactical nuclear weapons in Europe."

92 Gene Aloise and John Pendleton, Nuclear Weapons: DoD and NNSA Need to Better Manage Scope of Future Refurbishments and Risks to Maintaining U.S. Commitments to NATO, GAO 11-387 report to congressional requesters (Washington DC: United States Government Accountability Office, 2011), 5-10, accessed April 4, 2016, http://www.gao.gov/new.items/d11387.pdf. 
one year, and the other European host nations' readiness is at six months." ${ }^{93}$ It makes little difference whether or not these figures are precise. In fact, it is for the best that exact readiness levels are difficult to find in publically accessible sources. However, this does not change the capability gap. Given the well-documented conventional advantage Russia maintains on the eastern flank, a tactical nuclear DCA option could truly be the only one available in an immediate crisis. However, if it really takes NATO a minimum of thirty days to generate a tactical nuclear strike sortie, this option is neither realistic nor credible.

Considering the time and distance scenarios potentially available to Russia, this low level of readiness does not provide a credible deterrent. This is one area in which nuclear transparency is not beneficial - NATO must make its readiness levels classified. NORAD thirty-day response times in the US and Canada may be overkill, but nonetheless, these readiness levels all need to be increased beyond the timeframe of one month to be rendered credible. However, they should also not all be the same. By varying the readiness levels, host nations are able to maintain predictable schedules, allowing for any necessary training and reconstitution of forces. Meanwhile, the increased readiness levels provide the Alliance with short-notice capability and a credible deterrent. With the addition of Turkey and Poland, the Alliance could easily maintain two "high" readiness (less than forty-eight hours) units, four "moderate" readiness (less than thirty days) units, and one "low" readiness unit at all times. If indications and warnings ever prompt the Alliance to adjust these levels, the forces will be ready to meet the task.

\section{\#5: Creating a "NATO Strategic Deterrence Fund"}

Spending money, and specifically, earmarking it for nuclear deterrence, ticks all three boxes of deterrence: capability, credibility and communication. A creative 2016 American budget proposal could possibly serve as a blueprint for NATO's nuclear deterrence funding as well. US Secretary of Defense Ash Carter, appearing before the Senate Armed Services Committee in March 2016, gave public support to the idea of a national nuclear modernization fund for the first time. $^{94}$ In theory, this unique proposal appropriates the desired capacities and capabilities of the nuclear triad while avoiding placing a heavy burden on the Air Force and Navy. According to the James Martin Center for Nonproliferation Studies report in January of 2014, "Over the next thirty years, the United States plans to spend approximately $\$ 1$ trillion maintaining the current arsenal, buying replacement systems, and upgrading existing nuclear bombs and warheads." 95

93 Hans Kristensen, interviewed by the author, April 1, 2016.

94 Aaron Mehta, "Carter Open to DoD-wide Nuclear Weapons Fund," Defense News, March 18, 2016, accessed April 4, 2016, http://www.defensenews.com/story/ defense/policy-budget/budget/2016/03/18/carter-open-department-wide-nuclearweapons-fund/81972126/.

95 Jon Wolfsthal, Jeffrey Lewis, and Marc Quint, The Trillion Dollar Nuclear Triad (Monterey, California: James Martin Center for Nonproliferation Studies, January 2014), 
This "strategic deterrence fund" concept could serve a very useful and timely purpose within NATO. The highly publicized financial contributions to NATO on a national level, most recently highlighted by Trump, but more importantly by the last three American secretaries of defense, become the elephant in the room at every NATO summit.

Implementing this "nuclear tax" across all twenty-eight nations accomplishes multiple objectives. Strategically, it allows the Alliance to plan for and fund strategic deterrence, regardless of whether this entails nuclear weapons, for decades to come. Operationally, it first removes the financial burden borne by the five host nations in terms of funding DCA missions all by themselves. These missions are expensive, incurring costs for continued modernization and/ or replacement of aging DCA, security and storage for weapons, training and education etc. This fund could also help the US regain some of the $\$ 10$ billion it is spending on the B-61 LEP. ${ }^{96}$ Most importantly, similar to following the money trail left behind by terrorists, having individual nations funding the nuclear program gives nations ownership of the nuclear mission. Politically, it forces nations to have the long overdue, publicly debated discussions on what being part of a nuclear alliance means to the public - and whether it is worth paying for.

Realistically, however, those levying this "tax" on themselves, namely the twenty-eight heads of state, would likely never approve such a concept. Instead, they would likely point to the fact that non-US NATO alliance members, as former NATO Supreme Allied Commander, Admiral James Stavridis, describes: "spend a total of $\$ 300$ billion on defense - more than Russia and China's total defense spending." 97 It will take the US, leading from the front, not the rear, along with the nuclear-capable UK and France, to push the Alliance in this direction in Warsaw. Even if each nation only contributed one euro to the fund, that one euro would open valuable discussions within parliaments and in the public arena on the issue of appropriating money towards nuclear matters. The end result would be an open and honest discussion about being a nuclear alliance and whether or not individual countries are willing to pay for this capability - even if it is only one euro at stake.

\section{\#6: Creating a NATO nuclear declaratory statement}

By publishing a clear declaratory statement, NATO would further deter potential adversaries and reassure allies. Malcolm Chalmers describes the value of statements of this nature:

Actions speak louder than words, and the reality that no state has used nuclear weapons for more than six decades speaks more eloquently than any

accessed April 4, 2016, https://www.nonproliferation.org/wp-content/uploads/ 2016/04/140107_trillion_dollar_nuclear_triad.pdf.

96 Lewis, "A Steal at \$10 Billion."

97 Joseph J. Schatz and Benjamin Oreskes, "Europe to US: Ignore Donald Trump, we need NATO," Politico, April 1, 2016, accessed April 29, 2016, http://www.politico.eu/ article/europe-us-trump-we-need-nato-spending-military-alliance-cuts-russia/. 
declaratory policy could ever do. Yet, despite this reality-and indeed, to an extent, because of it-the statements that governments make about when, and for what purpose, they might use weapons remain a key element in deterrence and disarmament discourses. ${ }^{98}$

A NATO declaratory statement could help open the door to more transparent nuclear discussions within the Alliance, and within national governments as well. Just as the security environment changed after the Cold War, and again after Russia's actions in Crimea and Ukraine, NATO's declaratory statement should reflect these changes. Specifically, the statement should include language that includes a statement to the effect that "the use of any nuclear rhetoric or coercion during a crisis would immediately change the nature of the crisis." In addition, it should state that "the use of 'de-escalatory' nuclear strikes is unacceptable behavior that immediately changes the nature of a situation or conflict."

It should avoid being too narrow, such as proposing a "No First Use" policy. This is the exact policy Russia abandoned in 2000. ${ }^{99}$ This rules out the possibility of first use even at times where the existence of a nation state and its people are under immediate threat. At the same time, it should avoid being too broad in concept, stating that the "sole purpose" of the nuclear weapons are to be the deterrence of the use of such weapons, as in the policy held by China and India. An example of this in practice would be the use of nuclear weapons to destroy the nuclear forces of another state in order to prevent their use. While a pre-emptive (different from preventative) attack may seem logical and appropriate, it is nearly impossible to distinguish such an attack from a disarming first strike. In the end, a clear, nuclear declaratory statement, based on security vs. disarmament or non-proliferation, backed by the political will of twenty-eight nations, speaks volumes. As Chalmers also wrote, "It is a diplomatic norm that the sincerest form of declaration is one that is repeated often and at the highest level." ${ }^{100}$ Words matter. Communication is one of the "big three" of deterrence strategy. In an effort to counter Russia's nuclear saberrattling, there is no better time to publish a powerful declaratory statement than at the Warsaw Summit.

The bottom line: NATO must improve its communication. Most importantly, national leaders have to speak up and explain the advantages of solid nuclear policies and posture. NATO's information factsheets are worthless if national politicians do not make the case for necessary change.

98 Malcolm Chalmers, Nuclear Narratives: Reflections on Declaratory Policy (London: Royal United Services Institute, 2010), 3, accessed April 4, 2016, https://rusi.org/ sites/default/files/201005_whr_nuclear_narratives_0.pdf.

99 Kroenig, The Renewed Russian Nuclear Threat and NATO Nuclear Deterrence Posture.

${ }^{100}$ Chalmers, Nuclear Narratives, 8. 


\section{Conclusion}

In sum, this paper has considered the role and future of nuclear deterrence in the North Atlantic Alliance. The recommendations given cover a range of views, including military capabilities, political credibility and strategic communication. While the recommendations put forward range from the strategic to the tactical, they all aim to improve the overall health of deterrence. Given the growing threats from the east and the south with which the Alliance is faced, it is high time for the North Atlantic Treaty Organization to address the gaps and weak points in its nuclear deterrence strategy. Failure to do so puts the Alliance's primary mission, collective defense, at risk.

Following the Warsaw Summit of 2016, NATO must redefine and publicly declare what it means to be a "nuclear alliance." Simply maintaining a small stock of aging tactical nuclear weapons and aircraft in Europe neither deters adversaries nor reassures allies. In fact, it occasionally creates unwelcome political problems - as shown in 2009 by Germany's insistence on removing the weapons, then sudden volte-face and insistence that they should remain for the time being. Admittedly, nuclear deterrence forms only one part of NATO's overall deterrence strategy. However, these weapons have provided a successful transatlantic link for over five decades. They have linked Europe's freedom to the US's "supreme guarantee," the commitment to fight and die in a nuclear war to defend that freedom. Implementing significant changes to nuclear deterrence posture will no doubt be difficult, but it will not be impossible. Either way, the topic is not going to leave the table-no matter how badly the Alliance does not want to "deal" with a nuclear adversary-because in the end, the enemy always gets a vote. At the Warsaw Summit, NATO should set a course similar to that of the 2012 DDPR initiative: to modernize its nuclear deterrence in a manner that clearly communicates its credibility (political will) and military capability to any potential adversary today, or in the future.

\section{Disclaimer}

The author solely used open source, unclassified information for data collection on location and quantities of nuclear weapons, none of which were personally verified. The views expressed herein are those of the author and do not necessarily reflect the official policy or position of the Department of the Air Force, Department of Defense, or the US Government.

\section{About the author}

Lt. Col. Matt Anderson (USAF) is a command pilot and Senior Fellow the George C. Marshall European Center for Strategic Studies. 